\title{
Effects of titanium nanoparticles on adhesion, migration, proliferation, and differentiation of mesenchymal stem cells
}

This article was published in the following Dove Press journal:

International Journal of Nanomedicine

20 September 2013

Number of times this article has been viewed

\section{Yanhua Hou \\ Kaiyong Cai \\ Jinghua $\mathrm{Li}$ \\ Xiuyong Chen \\ Min Lai \\ Yan $\mathrm{Hu}$ \\ Zhong Luo \\ Xingwei Ding \\ Dawei Xu}

Key Laboratory of Biorheological

Science and Technology and

Ministry of Education,

College of Bioengineering,

Chongqing University, Chongqing,

People's Republic of China
Correspondence: Kaiyong Cai

College of Bioengineering, Chongqing

University, Chongqing 400044,

People's Republic of China

Tel +862365102507

Fax +862365102877

Email kaiyong_cai@cqu.edu.cn
Background: The purpose of this study was to investigate the influences of nanoscale wear particles derived from titanium/titanium alloy-based implants on integration of bone. Here we report the potential impact of titanium oxide $\left(\mathrm{TiO}_{2}\right)$ nanoparticles on adhesion, migration, proliferation, and differentiation of mesenchymal stem cells (MSC) from the cellular level to the molecular level in the Wistar rat.

Methods: A series of $\mathrm{TiO}_{2}$ nanoparticles $(14 \mathrm{~nm}, 108 \mathrm{~nm}$, and $196 \mathrm{~nm})$ were synthesized and characterized by scanning electron microscopy and transmission electron microscopy, respectively.

Results: The $\mathrm{TiO}_{2}$ nanoparticles had negative effects on cell viability, proliferation, and the cell cycle of MSC in a dose-dependent and size-dependent manner. Confocal laser scanning microscopy was used to investigate the effects of particle internalization on adhesion, spreading, and morphology of MSC. The integrity of the cell membrane, cytoskeleton, and vinculin of MSC were negatively influenced by large $\mathrm{TiO}_{2}$ nanoparticles.

Conclusion: The Transwell migration assay and a wound healing model suggested that $\mathrm{TiO}_{2}$ nanoparticles had a strong adverse impact on cell migration as particle size increased $(P<0.01)$. Furthermore, alkaline phosphatase, gene expression of osteocalcin (OC) and osteopontin (OPN), and mineralization measurements indicate that the size of the $\mathrm{TiO}_{2}$ nanoparticles negatively affected osteogenic differentiation of MSC.

Keywords: mesenchymal stem cells, titanium dioxide, nanoparticles, cytotoxicity, adhesion, migration

\section{Introduction}

Titanium and its alloys are widely used as bone implants in the clinical setting, mainly because of their good biocompatibility and mechanical properties. ${ }^{1,2}$ Nevertheless, owing to their inherent surface inertness, titanium-based implants can only integrate with the surrounding bone tissue via mechanical interlocking, and the ability to do this is closely related to surface topography at the microscale or nanoscale. ${ }^{3,4}$ Titanium substrates with a nanorough surface have been shown to influence cell adhesion, proliferation, and differentiation of osteoblasts. ${ }^{5}$ Guida et al confirmed that microscale or nanoscale modification of titanium substrates enhanced proliferation and synthesis of the extracellular matrix in human bone marrow-derived mesenchymal stem cells (MSC) and expression of osteoprotegerin. ${ }^{6}$ Annunziata et al also demonstrated that nanostructured titanium surfaces enhance adhesion and differentiation of human bone marrow-derived MSC. ${ }^{7}$ Thus, fabrication of titanium substrates with desirable topography has been a focus in the development of high quality titanium implants in 
recent decades. With the rapid development of nanotechnology, surface engineering of titanium using nanotopography to regulate cell behavior is now attracting much research attention. ${ }^{8,9}$ In our previous research, we confirmed that hierarchically microstructured or nanostructured surfaces ${ }^{10}$ and nanostructured titanium substrates ${ }^{11}$ could efficiently regulate the proliferation and differentiation of MSC.

However, in long-term clinical application (eg, titaniumbased hip joint implants), microscale and/or nanoscale wear particles can be generated at the implant/bone interface due to corrosion, aseptic loosening, and prosthesis friction. ${ }^{12,13}$ On the other hand, composite bone prostheses containing titanium nanoparticles may be released directly at the implant/bone interface. ${ }^{14}$ Previous studies have confirmed that microscale wear debris in the form of titanium particles released from a titanium implant occur in vivo, resulting in adverse effects, ie, significant attenuation of osteoblast function, increased osteoclast recruitment, and decreased bone integration. ${ }^{15,16}$

Given the worldwide concerns about nanotoxicity in biomaterials, the potential cytotoxicity of titanium nanoparticles has also been investigated in different cell lines. Previous studies have demonstrated that titanium nanoparticles have negative effects on cells, including inflammatory reactions in endothelial cells, ${ }^{17}$ damage to the DNA of human lymphoblastoid cells, ${ }^{18}$ and induction of micronuclei and apoptosis in Syrian hamster embryo fibroblasts. ${ }^{19}$ Other reports have shown that titanium dioxide $\left(\mathrm{TiO}_{2}\right)$ nanoparticles delivered to the abdominal cavity and liver in mice cause brain injury and liver damage, respectively. ${ }^{20,21}$ Wang et al also confirmed that $\mathrm{TiO}_{2}$ nanoparticles are potentially toxic to major organs and cause damage to the knee joints in rabbits due to their ability to catalyze oxidative DNA damage. ${ }^{22}$

To be able to confirm further the feasibility of development of surface nanostructured titanium-based bone implants, there is an urgent need for increased knowledge about how titanium nanoparticles affect biological function in cells involved in bone formation. In a previous study, we established a correlation between the cytotoxicity of $\mathrm{TiO}_{2}$ nanoparticles and different particle sizes on a sub$200 \mathrm{~nm}$ scale in respect to osteoblasts. ${ }^{23}$ In this study, we investigated the interaction between $\mathrm{TiO}_{2}$ nanoparticles and MSC. Although a previous study investigated the interaction between nanoparticles and neural stem cells, ${ }^{24}$ the effects of titanium nanoparticles on the biological behavior of bone marrow-derived MSC have not yet been reported. The rationale for choosing bone marrow-derived MSC was that the head of a titanium-based hip joint must be inserted into the medullary cavity of a long bone for fixation in clinical application, and the medullary cavity contains plentiful MSC. At this site, titanium implants can interact with MSC directly. In our previous study, ${ }^{23}$ we investigated the influence of different-sized titanium nanoparticles on the biological behavior of osteoblasts.

The objective of this study was to use titanium nanoparticles of different sizes mimicking the wear debris potentially loosening from a joint implant and to investigate how titanium nanoparticles influence the biological behavior of MSC, including cell adhesion, migration, proliferation, and differentiation.

\section{Materials and methods Materials}

Reagents used in this study, including fluorescein isothiocyanate (FITC), alkaline phosphatase (ALP), a bicinchoninic acid assay kit, Hoechst 33258, dexamethasone, L-ascorbate2-phosphate, 1,25-dihydroxy vitamin D3, b-glycerol phosphate, and alizarin red-S, were purchased from SigmaAldrich Chemical Co (St Louis, MO, USA). Rhodaminephalloidin was purchased from Invitrogen Co (Carlsbad, CA, USA). A CCK-8 assay kit was provided by Dojindo Laboratories (Kumamoto, Japan). Vinculin antibody was purchased from Santa Cruz Biotechnology Co (Santa Cruz, CA, USA). DyLight 649 goat anti-mouse secondary antibody was supplied by ZSGB-Bio Co (Beijing, People's Republic of China). Other reagents were sourced from Oriental Chemical Co (Chongqing, People's Republic of China).

\section{Synthesis and characterization of $\mathrm{TiO}_{2}$ nanoparticles}

A series of $\mathrm{TiO}_{2}$ nanoparticles was synthesized with a hydrothermal method. ${ }^{23}$ The morphological features of the $\mathrm{TiO}_{2}$ nanoparticles were characterized by field emission scanning electron microscopy (FEI Nova 400 Nano SEM, Philips, Eindhoven, The Netherlands) and transmission electron microscopy (TECNAI-10, Phillips), respectively.

\section{Cell culture}

MSC were isolated from the bone marrow of the femur and tibia of a Wistar rat (weight 150-200 g) using a technique reported previously. ${ }^{25}$ The MSC were cultured in a $75 \mathrm{~cm}^{2}$ flask containing $5 \mathrm{~mL}$ of Dulbecco's Modified Eagle's Medium supplemented with $10 \%$ bovine serum (Gibco, Grand Island, NY, USA) at $37^{\circ} \mathrm{C}$ in a $5 \% \mathrm{CO}_{2}$ atmosphere. The cell culture medium was changed on the first day and thereafter every 2 days. After reaching confluence, the cells were detached with $0.25 \%$ trypsin in $1 \mathrm{mM}$ 
tetrasodium EDTA, centrifuged, and resuspended in complete medium for reseeding in new culture flasks. The complete medium contained osteogenic supplements, ie, L-ascorbate2-phosphate $50 \mathrm{mg} / \mathrm{mL}$, dexamethasone $0.1 \mathrm{mM}$, b-glycerol phosphate $10 \mathrm{mM}$, and 1,25-dihydroxy vitamin D3 $10 \mathrm{nM}$. Cells at the third passage were used for our experiments.

\section{Cell viability assay}

The viability of MSC was examined using the CCK-8 assay kit. Briefly, the cells were cultured in a 24-well plate with or without (control) $\mathrm{TiO}_{2}$ particles at an initial seeding density of $2 \times 10^{4}$ cells $/ \mathrm{cm}^{2}$. For investigation of dose-dependent effects, MSC were incubated with different concentrations of $\mathrm{TiO}_{2}$ nanoparticles $(0.05,0.10$, and $0.20 \mathrm{mg} / \mathrm{mL})$ for 48 hours. For investigation of time-dependent effects, MSC were incubated with $\mathrm{TiO}_{2} 0.10 \mathrm{mg} / \mathrm{mL}$ nanoparticles for 3, 7, and 14 days. CCK-8 kit reagents were added to each well according to the manufacturer's instructions. Absorbance was measured using a microplate reader (model 550, Bio-Rad Laboratories, Hercules, CA, USA) at a wavelength of $450 \mathrm{~nm}(\mathrm{n}=6)$.

\section{Cell cycle assay using flow cytometry}

The cells were cultured in a $24-w e l l$ plate at an initial cell seeding density of $1 \times 10^{5}$ cells $/ \mathrm{cm}^{2}$. $\mathrm{TiO}_{2}$ nanoparticles were added into each well when cell confluence reached around $70 \%$, and the final concentration of nanoparticles was adjusted to $0.10 \mathrm{mg} / \mathrm{mL}$. After culture for one, two, and three days, the cells were washed twice with phosphatebuffered solution and centrifuged. The cells were then fixed with $70 \%$ ethanol at $4{ }^{\circ} \mathrm{C}$ for one hour and washed with phosphate-buffered solution. Next, the treated cells were resuspended with propidium iodide solution $0.05 \mathrm{mg} / \mathrm{mL}$ containing RNase and incubated in the dark at room temperature for 30 minutes. The DNA content of the cells was then analyzed using a flow cytometer (EPICS XL-MCL, Beckman Coulter, Fullerton, CA, USA).

\section{Particle internalization assay}

FITC-TiO ${ }_{2}$ nanoparticles were constructed in a manner reported elsewhere ${ }^{26}$ and their translocation was investigated. Briefly, $15 \mathrm{mg}$ of $\mathrm{TiO}_{2}$ nanoparticles were suspended in $1 \mathrm{~mL}$ of distilled water and treated with ultrasonication at room temperature for 45 minutes. The sample was then centrifuged to remove the aqueous solution. Next, $0.4 \mathrm{~mL}$ of dopamine $1 \mathrm{mM}$ solution was added with stirring for 10 minutes. After removal of the free dopamine by centrifugation, the resulting dopamine-modified $\mathrm{TiO}_{2}$ nanoparticles were further reacted with FITC to yield FITC-labeled $\mathrm{TiO}_{2}$ nanoparticles.
Free FITC molecules were removed by centrifugation. FITC-labeled $\mathrm{TiO}_{2}$ nanoparticles were resuspended in phosphate-buffered solution for further experiments. Cells were cocultured with or without (control) $\mathrm{FITC}-\mathrm{TiO}_{2}$ nanoparticles for 24 hours. Internalization of the $\mathrm{TiO}_{2}$ nanoparticles was investigated by confocal laser scanning microscopy (TCS SP5, Leica Microsystems, Wetzlar, Germany).

\section{Cell adhesion}

MSC were cultured with $0.10 \mathrm{mg} / \mathrm{mL}$ of FITC-TiO ${ }_{2}$ nanoparticles for 12 and 24 hours, respectively. The cells were washed with phosphate-buffered solution three times and fixed with $4 \%$ paraformaldehyde at $4^{\circ} \mathrm{C}$ for 30 minutes. The treated cells were then permeabilized with $0.25 \%$ Triton X-100 for 10 minutes and washed with phosphate-buffered solution three times. Next, the cells were incubated with $5 \%$ bovine serum albumin/phosphate-buffered solution at $37^{\circ} \mathrm{C}$ for one hour. Subsequently, mouse monoclonal antibody against vinculin $(1: 200)$ was added and incubated at $4{ }^{\circ} \mathrm{C}$ overnight. Next, DyLight 649 goat anti-mouse secondary antibody $(1: 100)$ was added and incubated at $37^{\circ} \mathrm{C}$ for a further hour. Subsequently, the cells were stained with $5 \mathrm{U} / \mathrm{mL}$ of rhodamine-phalloidin at $4{ }^{\circ} \mathrm{C}$ overnight and counterstained with $10 \mu \mathrm{g} / \mathrm{mL}$ of Hoechst 33258 at room temperature for 5 minutes. Finally, the cells were mounted with $95 \%$ glycerinum and visualized by confocal laser scanning microscopy.

\section{Wound healing}

Wound healing experiments were performed for quantitative investigation of the migration of MSC when stimulated by $\mathrm{TiO}_{2}$ nanoparticles of different sizes. MSC were incubated without (control) or with the different $\mathrm{TiO}_{2}$ nanoparticles $(0.10 \mathrm{mg} / \mathrm{mL})$ at $37^{\circ} \mathrm{C}$ for 4 hours. The initial cell seeding density was $1 \times 10^{5}$ cells $/ \mathrm{cm}^{2}$. A linear wound was made by scratching with a cell scraper. The cells were washed twice with phosphate-buffered solution and incubated with fresh medium for another 12 and 16 hours, respectively. Cells were then visualized by confocal laser scanning microscopy.

\section{Transwell assay}

A further cell migration assay was performed as reported elsewhere. ${ }^{27}$ MSC were cultured with $\mathrm{TiO}_{2}$ nanoparticles $(0.10 \mathrm{mg} / \mathrm{mL})$ for 8 hours. After detaching with trypsin, the treated cells were seeded into a Millicell (Greiner Bio-One, Frickenhausen, Germany) containing pores $8 \mu \mathrm{m}$ in diameter at an initial seeding density of $1 \times 10^{5}$ cells $/ \mathrm{cm}^{2}$ suspended in Dulbecco's Modified Eagle's Medium containing 1\% 
fetal bovine serum. Next, the Millicell was put into the well of a 24-well plate containing 20\% fetal bovine serum in Dulbecco's Modified Eagle's Medium. The cells were allowed to migrate at $37^{\circ} \mathrm{C}$ for another 8 hours. After staining with crystal violet $(0.1 \mathrm{wt} \%)$, the migrated cell clones were recorded using an optical microscope. The cell number was counted at 12 different areas, and the data were averaged from three parallel experiments and normalized by data from the control group.

\section{Total intracellular protein content}

MSC were cultured without or with $\mathrm{TiO}_{2}$ nanoparticles $(0.10 \mathrm{mg} / \mathrm{mL})$ in Dulbecco's Modified Eagle's Medium with $10 \%$ fetal bovine serum for 7 and 14 days, respectively. The initial cell seeding density was $2 \times 10^{4}$ cells $/ \mathrm{cm}^{2}$. At prescribed time intervals, the cells were lysed using $1 \%$ Triton X-100 with three freeze-thaw cycles. Total protein content in the cell lysates was determined spectrophotometrically using a commercially available kit (bicinchoninic acid, Sigma-Aldrich). The light absorbance of the samples was measured at $570 \mathrm{~nm}$ with the Bio-Rad 550 spectrophotometric microplate reader. Total intracellular protein (expressed as mg) synthesized by the cells was determined from a standard curve of absorbance versus the known concentration of albumin run in parallel experiments.

\section{Alkaline phosphatase activity}

Cells were incubated with $0.10 \mathrm{mg} / \mathrm{mL} \mathrm{TiO}_{2}$ particles for 7 and 14 days, respectively. The initial seeding density was $2 \times 10^{4}$ cells $/ \mathrm{cm}^{2}$. Cells were then collected and lysed as mentioned above. The supernatant was used for determining ALP activity, with paranitrophenyl phosphate as a substrate. Absorbance at $405 \mathrm{~nm}$ was measured using a spectrophotometer in a 96-well microplate reader (Bio-Rad 550). ALP activity (expressed as nmol of p-nitrophenol converted per minute) was normalized by total intracellular protein synthesis and expressed as mol p-nitrophenol per minute per mg protein. The ALP activity of MSC cultured without $\mathrm{TiO}_{2}$ particles was used as the control.

\section{Mineralization}

Cell mineralization was quantitatively measured after alizarin red-S staining elution as described elsewhere. ${ }^{28}$ Briefly, MSC were incubated with $\mathrm{TiO}_{2}$ particles $(0.10 \mathrm{mg} / \mathrm{mL})$ for 15 days at an initial seeding density of $5 \times 10^{4}$ cells $/ \mathrm{cm}^{2}$. The cells were washed with phosphate-buffered solution and fixed with $2 \%$ glutaraldehyde at $4^{\circ} \mathrm{C}$ for 20 minutes. The samples were then washed three times in distilled water and stained with $40 \mathrm{Mm}$ alizarin red-S ( $\mathrm{pH} 4.1)$ with shaking at room temperature for 20 minutes. Next, $400 \mu \mathrm{L}$ of $10 \%$ acetic acid was added to each well and incubated for another 30 minutes with shaking. The cell monolayer was then scraped with a cell scraper and transferred into a $1.5 \mathrm{~mL}$ tube with $10 \%$ acetic acid. Samples were heated up to $85^{\circ} \mathrm{C}$ for 10 minutes and centrifuged at 20,000 g for 15 minutes. Subsequently, $300 \mu \mathrm{L}$ of the supernatant was transferred into a new tube and neutralized with $200 \mu \mathrm{L}$ of $10 \%$ ammonium hydroxide. The absorbance of supernatant $(100 \mu \mathrm{L})$ was measured at a wavelength of $405 \mathrm{~nm}$ using a spectrophotometric microplate reader (Bio-Rad 680). Cell mineralization was finally normalized for protein content.

\section{Reverse transcription polymerase chain reaction}

Cells were collected after culture for 14 days. The total RNA in the cells was extracted according to the instructions on an RNA extract kit (Bio-Tek Instruments Inc., Winooski, VT, USA). Aliquots of total RNA ( $5 \mathrm{~mL}$ ) were reverse transcribed, and a $5 \mathrm{~mL}$ cDNA sample was amplified. The following oligonucleotide primer pairs related to the targeted RNA were used in this study: $\beta$-actin, $5^{\prime}$-ATATCGCTGCGCTGGTCGTC-3' and 5'-AGGATGGCGTGAGGGAGAGC-3'; osteocalcin, 5'-TGGCCCTGACTGCATTCTGC-3' and 5'-GCTGTGCCGTCCATACTTTCG-3'; and osteopontin, 5'-CCTCTGAAGAAACGGAT GACT-3' and 5'-CTGTGTGTTTCCACGCTT-3'. The polymerase chain reaction conditions were as follows: first cycle at $94^{\circ} \mathrm{C}$ for 5 minutes, followed by 35 cycles at $94^{\circ} \mathrm{C}$ for 30 seconds, $56^{\circ} \mathrm{C}$ for 30 seconds, and $72^{\circ} \mathrm{C}$ for 30 seconds, and the final cycle at $72^{\circ} \mathrm{C}$ for 10 minutes. The amplified cDNA was analyzed by gel electrophoresis with $1.5 \%$ agarose gel.

\section{Statistical analysis}

All data are expressed as the mean \pm standard deviation. The statistical analysis was performed using the Student's $t$-test and one-way analysis of variance at confidence levels of $95 \%$ and $99 \%$ (OriginPro, version 7.5).

\section{Results}

\section{Synthesis and characterization of $\mathrm{TiO}_{2}$ nanoparticles}

$\mathrm{TiO}_{2}$ nanoparticles of different sizes were home-synthesized by a hydrothermal method, ${ }^{29}$ and characterized by scanning and transmission electron microscopy, respectively. Three types of $\mathrm{TiO}_{2}$ nanoparticles with average particle sizes of 
$14 \mathrm{~nm}, 108 \mathrm{~nm}$, and $196 \mathrm{~nm}$ were synthesized by simply changing the ratios of peptizing agents, titanium precursor solution (titanium butoxide), and reaction time. Scanning and transmission electron microscopic images (Figure 1) show that the $\mathrm{TiO}_{2}$ nanoparticles had a relatively uniform morphology with a narrow size distribution.

\section{Cell viability and proliferation assay}

A CCK-8 kit was used to investigate the influence of $\mathrm{TiO}_{2}$ nanoparticles on the biological behavior of MSC, ie, their
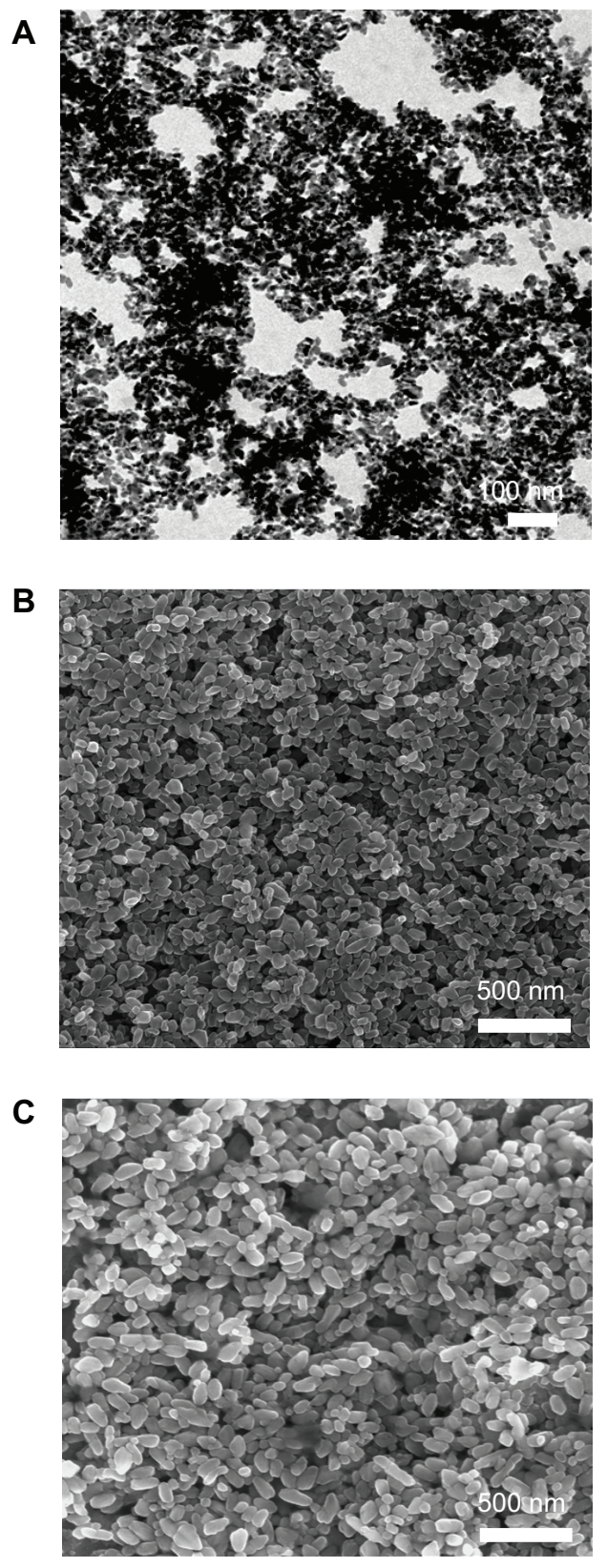

Figure I Characterization of $\mathrm{TiO}_{2}$ nanoparticles with different sizes from scanning electron microscopy observation (except for A from transmission electron microscopy observation). (A) $14 \mathrm{~nm}$, (B) $108 \mathrm{~nm}$, and (C) $196 \mathrm{~nm}$. potential cytotoxicity. First, we investigated the dosedependent effects of $\mathrm{TiO}_{2}$ nanoparticles on the viability of MSC. The results show that high concentrations of $\mathrm{TiO}_{2}$ nanoparticles $(0.10$ and $0.20 \mathrm{mg} / \mathrm{mL})$ had strong adverse effects on the viability of MSC (Figure 2).

Second, we investigated the effects of $\mathrm{TiO}_{2}$ nanoparticle size on cell proliferation (Figure 3 ). MSC were cultured with $\mathrm{TiO}_{2}$ nanoparticles $(0.10 \mathrm{mg} / \mathrm{mL})$ for 3,7 , and 14 days. The results show that the negative effect increased significantly with increasing particle size. After culture for 3 days with $\mathrm{TiO}_{2}$ nanoparticles $196 \mathrm{~nm}$ in size, relative cell viability decreased to $51.73 \%$ compared with the control group. Relative cell viability decreased further to $36.39 \%$ and $34.92 \%$ after culture for 7 and 14 days, respectively. Over all time intervals, the $\mathrm{TiO}_{2}$ nanoparticles showed a clear tendency for size-dependent inhibition of growth $(P<0.01)$.

Third, we investigated the influence of different-sized $\mathrm{TiO}_{2}$ nanoparticles on cell division by flow cytometry to show the cell cycle during proliferation. Previous research has suggested that metal nanoparticles might potentially induce oxidative stress, leading to intracellular changes and alterations in the cell cycle. ${ }^{30}$ In this study, we measured the change in percent proliferation index (percent synthesis phase of DNA $[\% \mathrm{~S}]+$ percent post-synthesis phase of DNA $\left.\left[\% \mathrm{G}_{2}\right]\right)$ in the cell cycle to indicate the effects of the $\mathrm{TiO}_{2}$ nanoparticles on MSC.

The percentage of $\mathrm{TiO}_{2}$ nanoparticle-treated MSC in G1 phase increased when compared with that of the control after culture for one, two, and three days, respectively. Accordingly, the percent proliferation index $\left(\% \mathrm{~S}+\% \mathrm{G}_{2}\right)$ of MSC treated with $\mathrm{TiO}_{2}$ nanoparticles decreased after culture for one, two, and three days (Table 1). Further, inhibition of

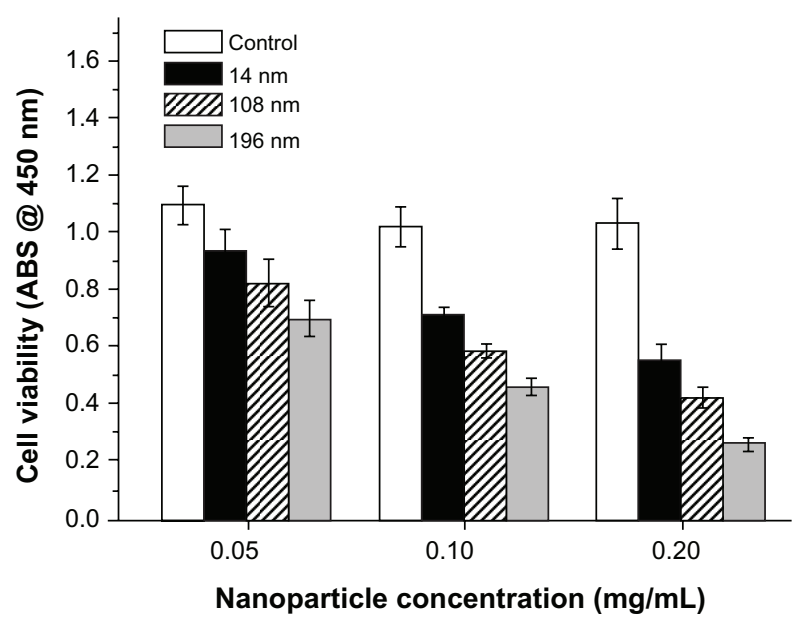

Figure 2 Dose-dependent effects of various nanoparticles on cell viability after culture for 2 days. The initial cell seeding density was $2 \times 10^{4} \mathrm{cells} / \mathrm{cm}^{2}$. Abbreviation: ABS, absorbance. 


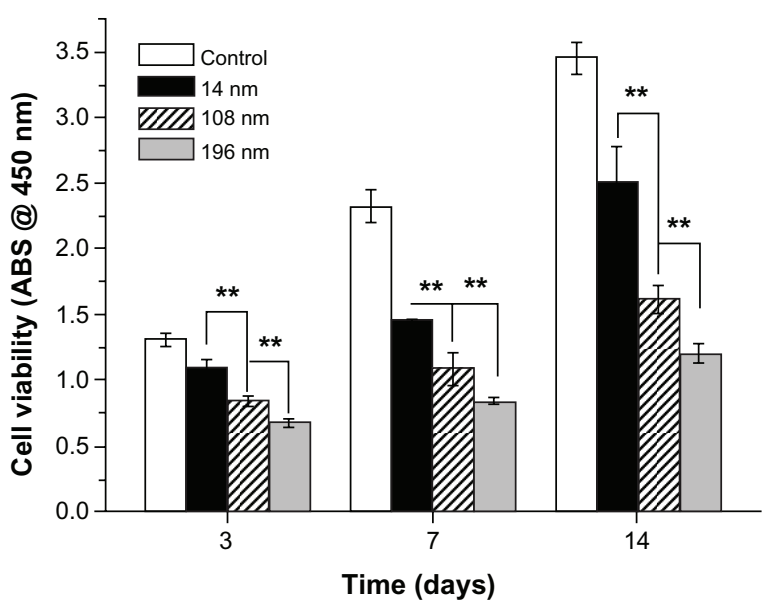

Figure 3 Viability of mesenchymal stem cells incubated with various $\mathrm{TiO}_{2}$ nanoparticles for different time periods.

Notes: The initial cell seeding density was $2 \times 10^{4} \mathrm{cells} / \mathrm{cm}^{2}$. Error bars represent the mean \pm standard deviation for $\mathrm{n}=6$, $* * P<0.0$ l.

Abbreviation: $A B S$, absorbance.

proliferation of the $\mathrm{TiO}_{2}$ nanoparticles was also dependent on their particle size at each time interval. In particular, the percent proliferation index of MSC treated with $196 \mathrm{~nm} \mathrm{TiO}_{2}$ nanoparticles decreased 2.51-fold compared with controls after culture for 3 days. This result indicates that the change in percent proliferation index for the MSC was mediated mainly by the size of the $\mathrm{TiO}_{2}$ nanoparticles. This finding was consistent with a previous study showing that polystyrene nanoparticle size and charge had a pronounced effect on mitotic spindle formation and chromosomes during cell division. ${ }^{31}$ Moreover, other studies have demonstrated that DNA strand breaks were related to cell cycle arrest and cell death in epithelial cells treated with $\mathrm{TiO}_{2}$ nanoparticles and copper dioxide nanoparticles. . $^{32,33}$

Table I Cell cycle analysis. Cells were incubated without (control) or with various titanium dioxide nanoparticles for one, two, and three days, respectively

\begin{tabular}{llllll}
\hline Time (days) & Samples & $\mathbf{G}_{1} \%$ & $\mathbf{S} \%$ & $\mathbf{G}_{2} \%$ & $\mathbf{P I}\left(\mathbf{S}+\mathbf{G}_{2}\right) \%$ \\
\hline $\mathrm{I}$ & Control & 71.30 & 18.60 & 10.10 & 28.70 \\
& I4 nm & 72.30 & 12.30 & 15.40 & 27.70 \\
& $108 \mathrm{~nm}$ & 77.24 & 5.76 & 17.00 & 22.76 \\
& $196 \mathrm{~nm}$ & 82.08 & 3.72 & 14.20 & 17.92 \\
& Control & 69.80 & 11.60 & 18.60 & 30.20 \\
& $14 \mathrm{~nm}$ & 73.51 & 5.79 & 20.70 & 26.49 \\
& $108 \mathrm{~nm}$ & 79.41 & 8.79 & 11.80 & 20.59 \\
3 & $196 \mathrm{~nm}$ & 84.23 & 8.07 & 7.70 & 15.77 \\
& Control & 67.39 & 12.20 & 20.40 & 32.60 \\
& $14 \mathrm{~nm}$ & 75.85 & 8.050 & 16.10 & 24.15 \\
& $108 \mathrm{~nm}$ & 78.05 & 13.00 & 8.95 & 21.95 \\
& $196 \mathrm{~nm}$ & 87.00 & 5.21 & 7.79 & 13.00
\end{tabular}

Notes: Initial cell seeding density was $1 \times 10^{5} \mathrm{cells} / \mathrm{cm}^{2}$. DNA content was analyzed by flow cytometry. $G_{1}, S$, and $G_{2}$ indicate cell cycle phases.

Abbreviation: Pl, proliferation index; DNA, deoxyribonucleic acid.

\section{Particle internalization and cell adhesion}

To identify the location of $\mathrm{TiO}_{2}$ nanoparticles within cells and the effect of particle size on adhesion of MSC, FITC-TiO particles (green), vinculin (focal adhesion protein, cyan), actin (cytoskeleton) filaments (red), and cell nuclei (blue) were visualized by confocal laser scanning microscopy. MSC cultured without (control) or with FITC- $\mathrm{TiO}_{2}$ nanoparticles of different sizes were observed after culture for 12 and 24 hours (Figure 4A), respectively. Large amounts of FITC-TiO ${ }_{2}$ nanoparticles (108 nm and $196 \mathrm{~nm}$ ) were observed to accumulate in MSC (green). Moreover, the digested nanoparticles were only distributed in the cytoplasm rather than the nuclei of MSC. The same phenomenon was also observed in previous studies of neural stem cells ${ }^{24}$ and fibroblasts. ${ }^{34}$

Adhesion is the first response of the cell when it comes into contact with a biomaterial, and plays an essential role in regulation of the subsequent biological behavior of cells. Previous research indicates that the adaptor protein of vinculin is a key regulator of focal adhesion, which is activated by binding of talin. ${ }^{35}$ Compared with the controls, a distinct difference was observed regarding cell adhesion (vinculin spots, arrows) and the cytoskeletons of MSC treated with $\mathrm{TiO}_{2}$ nanoparticles. The larger the size of the $\mathrm{TiO}_{2}$ nanoparticles, the lower the amount of vinculin that was present (Figure 4A). A similar tendency was also observed for cell spreading, indicated by distribution of actin within cells.

The amount of vinculin in MSC treated with $14 \mathrm{~nm} \mathrm{TiO}_{2}$ nanoparticles was significantly greater $(P<0.01)$ than that in MSC treated with $108 \mathrm{~nm} \mathrm{TiO}_{2}$ nanoparticles, and yet greater $(P<0.01)$ in MSC treated with $196 \mathrm{~nm} \mathrm{TiO}_{2}$ nanoparticles after culture for 24 hours (Figure 4B). The average amount of vinculin in MSC treated with $196 \mathrm{~nm} \mathrm{TiO} 2$ nanoparticles decreased to $63.4 \%$ of control levels after culture for 12 hours, and decreased further to $51.3 \%$ of control levels after culture for 24 hours. These results suggest that $\mathrm{TiO}_{2}$ nanoparticle size strongly affects adhesion of MSC, which is consistent with previous reports. ${ }^{16,36}$

\section{Cell migration}

Focal adhesion of cells generally has a close relationship with cell migration. ${ }^{37}$ To investigate the effect of $\mathrm{TiO}_{2}$ nanoparticles on cell migration, a wound healing (scrape migration) assay was performed, as described elsewhere. ${ }^{38}$ After culture for 12 hours, many cells treated with $14 \mathrm{~nm}$ $\mathrm{TiO}_{2}$ nanoparticles migrated to the center of the wound field, whereas few cells treated with $108 \mathrm{~nm} \mathrm{TiO}_{2}$ nanoparticles and even fewer cells treated with $196 \mathrm{~nm} \mathrm{TiO}_{2}$ nanoparticles did so (Figure 5). 
A
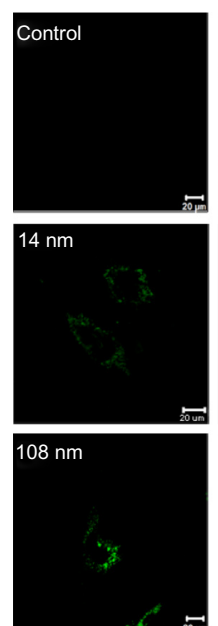

$196 \mathrm{~nm}$

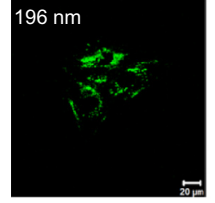

.

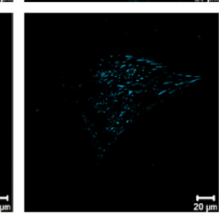

12 hours
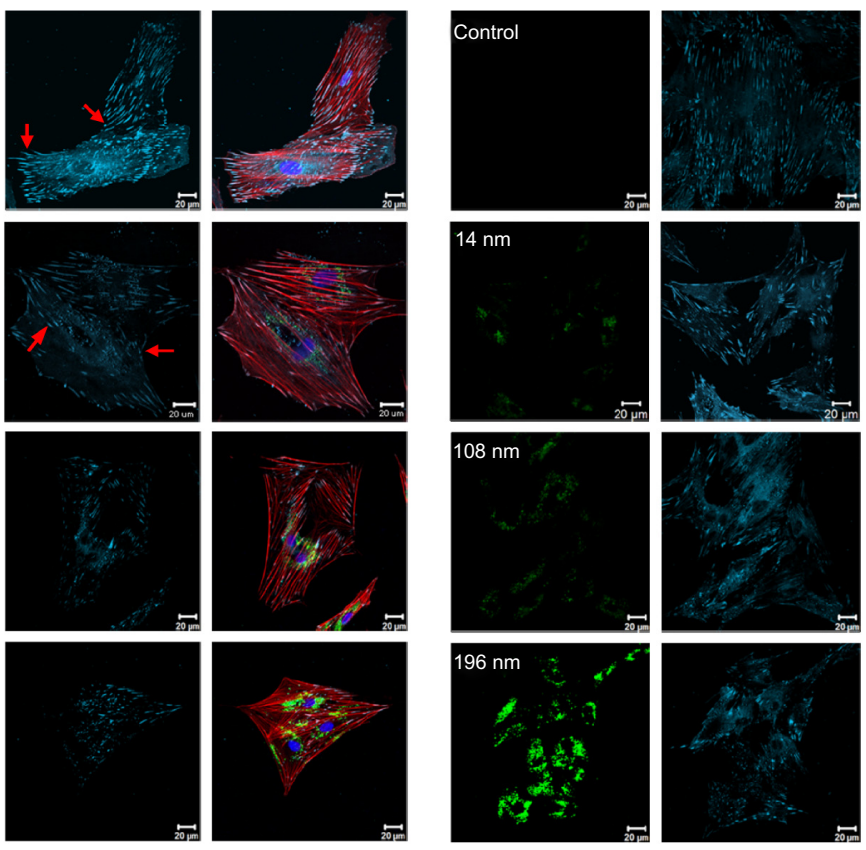

24 hours
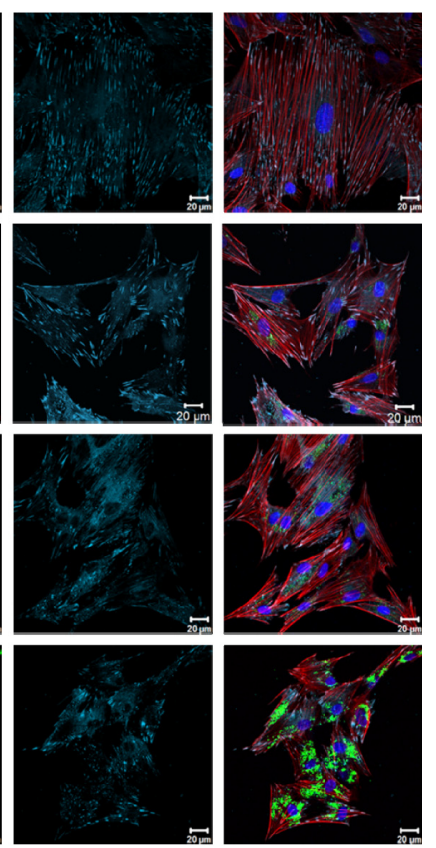

$x=$

\section{B}

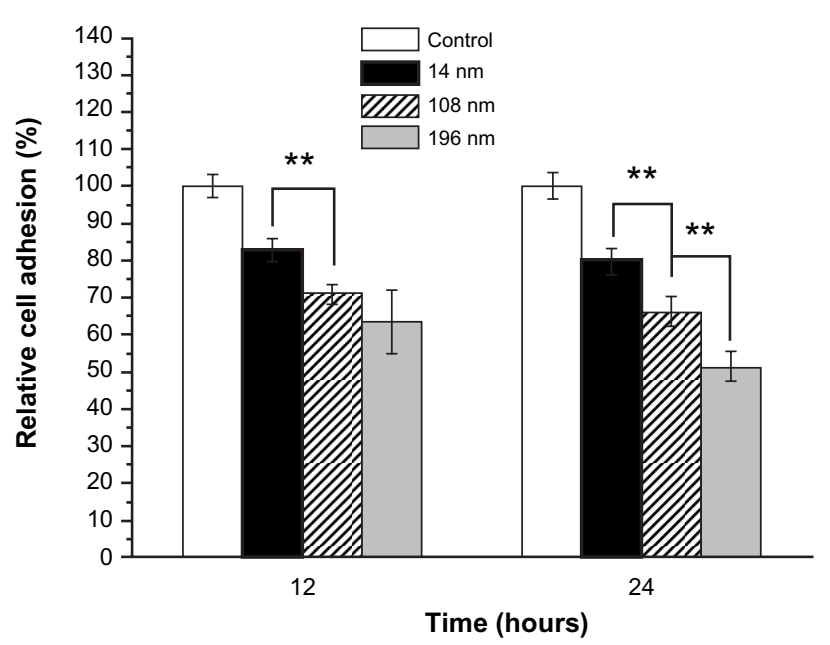

Figure 4 (A) Confocal microscopic images of mesenchymal stem cells incubated without (control) or with FITC-TiO, particles $(0.10 \mathrm{mg} / \mathrm{mL})$ for 12 and 24 hours, respectively. FITC-TiO 2 particles (green), vinculin (cyan), actin filaments (red), and cell nuclei (blue). Scale bar $=20 \mu m$. (B) Relative fluorescence intensity analysis of vinculin. Average fluorescence intensity per cell was normalized to the control sample.

Notes: Error bars represent the mean \pm standard deviation for $n=50$, ** $p<0.01$

Abbreviation: FITC, fluorescein isothiocyanate.

To investigate further the effects of $\mathrm{TiO}_{2}$ nanoparticles on cell migration, a matrigel invasion assay was performed using Transwell chambers. Figure 6A shows representative images for control MSC and those treated with $\mathrm{TiO}_{2}$ nanoparticles. Quantitative analysis showed that treatment with $\mathrm{TiO}_{2}$ nanoparticles significantly decreased migration of MSC. Moreover, the relative migration of MSC treated with $14 \mathrm{~nm}$ $\mathrm{TiO}_{2}$ nanoparticles was significantly greater $(P<0.01)$ than that of MSC treated with $108 \mathrm{~nm} \mathrm{TiO}_{2}$ nanoparticles, and yet higher $(P<0.01)$ than migration of MSC treated with $196 \mathrm{~nm} \mathrm{TiO}{ }_{2}$ nanoparticles (Figure 6B). Our results suggest that $\mathrm{TiO}_{2}$ nanoparticle size strongly affects migration of MSC, and are consistent with those of a previous study of hydroxyapatite nanoparticles. ${ }^{39}$

\section{Cell differentiation}

To investigate the effects of $\mathrm{TiO}_{2}$ nanoparticles on osteogenic differentiation of MSC, we firstly measured ALP activity 


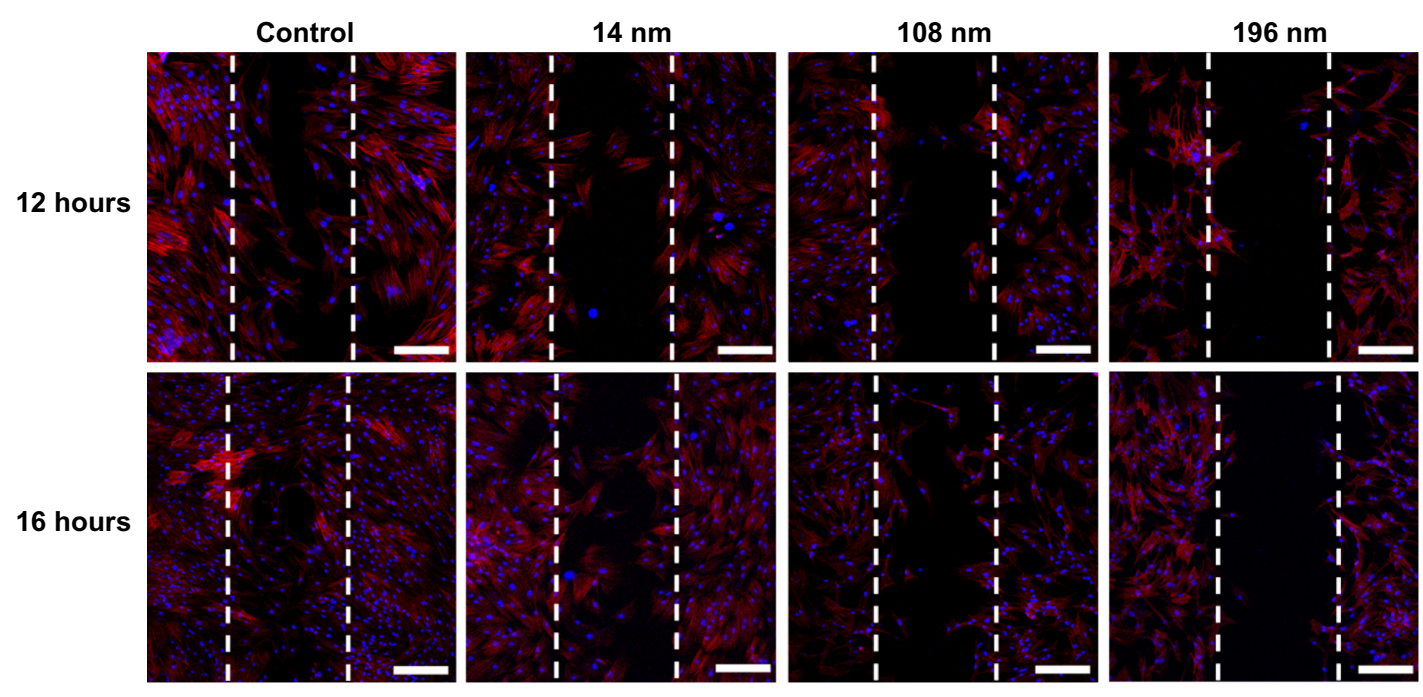

Figure 5 Wound healing in mesenchymal stem cells incubated without (control) or with different TiO, particles $(0.10 \mathrm{mg} / \mathrm{mL})$ shown by confocal laser scanning microscopy. Notes: Scale bar $=100 \mu \mathrm{m}$. The initial cell seeding density was $1 \times 10^{5} \mathrm{cells} / \mathrm{cm}^{2}$.

in MSC treated with different-sized $\mathrm{TiO}_{2}$ nanoparticles (Figure 7). ALP is an early mineralization-related protein marker for osteogenesis of osteoblasts. ${ }^{40}$ MSC cultured with different-sized $\mathrm{TiO}_{2}$ nanoparticles showed significantly weaker $(P<0.01)$ ALP activity than the control group at all time points. After culture for 7 days, MSC treated with $14 \mathrm{~nm}$ and $108 \mathrm{~nm} \mathrm{TiO}_{2}$ nanoparticles demonstrated significantly higher $(P<0.01)$ ALP activity than those treated with $196 \mathrm{~nm} \mathrm{TiO}{ }_{2}$ nanoparticles. After culture for 14 days, MSC treated with $14 \mathrm{~nm} \mathrm{TiO}_{2}$ nanoparticles showed significantly more $(P<0.01)$ ALP activity than those treated with $108 \mathrm{~nm}$ and $196 \mathrm{~nm} \mathrm{TiO}_{2}$ nanoparticles. Next, we measured mineralization ability in MSC treated with $\mathrm{TiO}_{2}$ nanoparticles of different sizes. The normalized mineralization demonstrated a trend similar to that for ALP activity after culture for 15 days (Figure 8).

To investigate further the impact of $\mathrm{TiO}_{2}$ nanoparticles on differentiation of MSC, we characterized messenger RNA (mRNA) expression of osteocalcin and osteopontin by reverse transcription polymerase chain reaction. Osteocalcin and osteopontin are noncollagenous matrix proteins, which are regarded as mature osteoblast markers in MSC at a late stage. ${ }^{41}$ We found that MSC treated with $196 \mathrm{~nm} \mathrm{TiO}_{2}$ nanoparticles produced significantly less $(P<0.05$ and $P<0.01)$ osteocalcin and osteopontin, respectively, than MSC treated with $14 \mathrm{~nm}$ and $108 \mathrm{~nm} \mathrm{TiO}_{2}$ nanoparticles (Figure 9). This result is consistent with the findings of a previous study showing that calcium phosphate-based particles of increasing size impaired osteogenic differentiation and bone matrix mineralization in MSC. ${ }^{42}$ However, other research has confirmed that a high dose of zinc oxide nanoparticles is lethal to proliferating pluripotent MSC but has negligible toxicity in osteogenically differentiated MSC. ${ }^{43}$ Nanohydroxyapatite and nanohydroxyapatite-poly(lactic-co-glycolic acid) (PLGA) composites promote osteogenic differentiation of human MSC. ${ }^{44}$ In another study, iron oxide nanoparticles of different sizes and surface charge were found to regulate the differentiation of MSC. ${ }^{45}$

\section{Discussion}

In recent years, much effort has been made to improve the properties of nanostructured titanium implants. ${ }^{3,7,8,10}$ Nevertheless, nanoscale wear debris could potentially be generated during long-term implantation in the clinical setting, mainly because of abrasion and invasion of various enzymes and chemicals in an environment containing biological fluids. Therefore, investigation of the potential cytotoxicity of nanoscale debris released from a titanium implant is essential.

The head of a titanium joint implant not only comes into contact with osteoblasts derived from the surrounding bone tissue but also interacts with bone marrow stem cells in the long bone cavity. In a previous study ${ }^{23}$ we highlighted the size-dependent negative effects of different titanium nanoparticles on viability of osteoblasts, liver cells (L-02), and kidney cells (HEK 293), and investigated the size-dependent cellular uptake pathways and activation of matrix metalloproteinase 9. In this study, we used titanium nanoparticles (ie, a debris model) to investigate how titanium nanoparticles of different sizes affect adhesion and proliferation (ie, DNA synthesis), osteocalcin and osteopontin gene expression, and migration of MSC. Investigating the migration of MSC surrounding a titanium implant is of particular importance for 


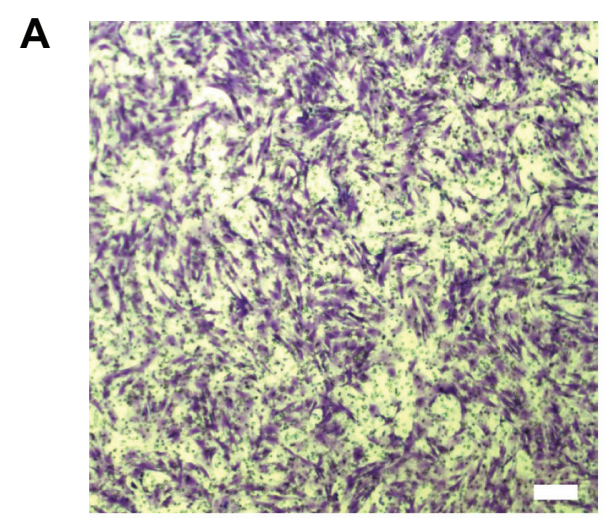

a

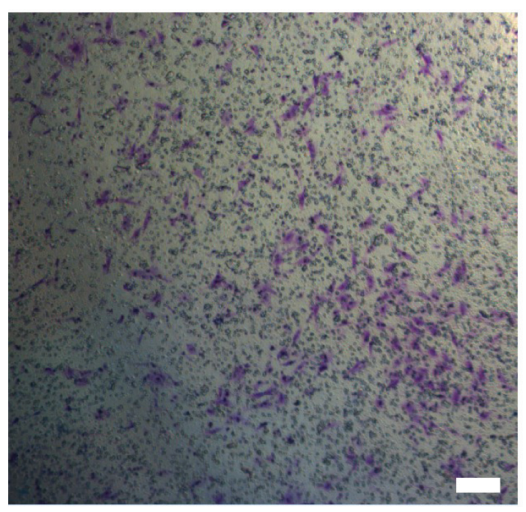

C

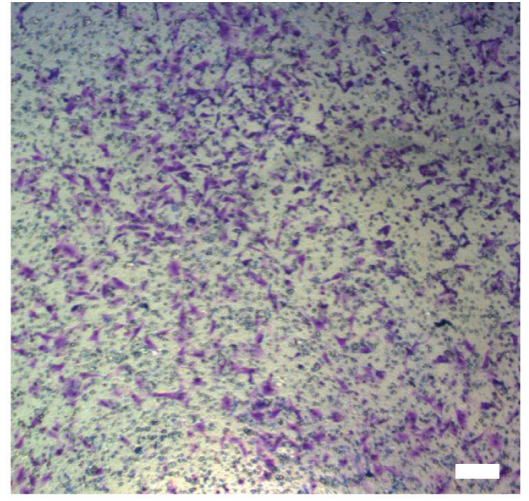

b

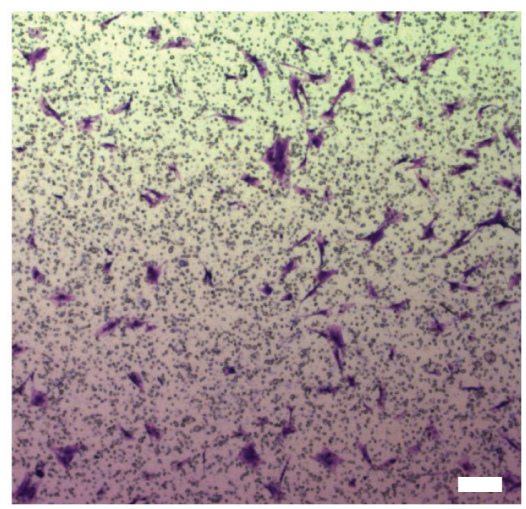

d

B

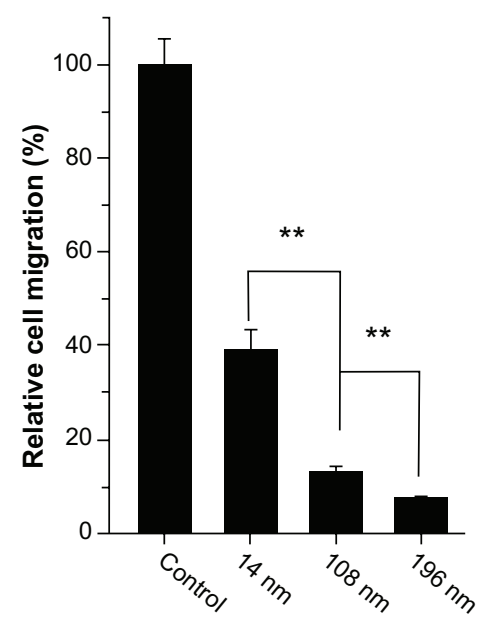

Figure 6 Characterization of cell migration. (A) Qualitative cell migration assay shown by Transwell assay after culture for 8 hours. a: control; b: 14 nm; c: $108 \mathrm{~nm}$; d: 196 $\mathrm{nm}$; and (B) quantitative analysis of relative cell migration from $A(n=100)$.

Notes: The initial cell seeding density was $\mathrm{I} \times 10^{5} \mathrm{cells} / \mathrm{cm}^{2}$. Scale bar $=100 \mu \mathrm{m}$. $* * P<0.01$.

understanding how MSC potentially contribute to osseous integration in implant/bone tissue.

Once wear debris (ie, $\mathrm{TiO}_{2}$ nanoparticle model) detaches from a titanium implant, it can affect the biological function of the surrounding cells in two ways, firstly by affecting protein adsorption around cells and secondly by being taken up directly by cells. The extent of this in both cases depends on particle size and nanotopography. However, the exact contribution of each factor needs to be investigated in more depth. Our interest was focused on the latter in this study.

Our results confirmed that the synthesized $\mathrm{TiO}_{2}$ nanoparticles (14 nm, $108 \mathrm{~nm}$, and $196 \mathrm{~nm}$ ) had a cytotoxic effect on MSC depending on their concentration (Figure 2). This phenomenon could be interpreted as highly concentrated $\mathrm{TiO}_{2}$ 


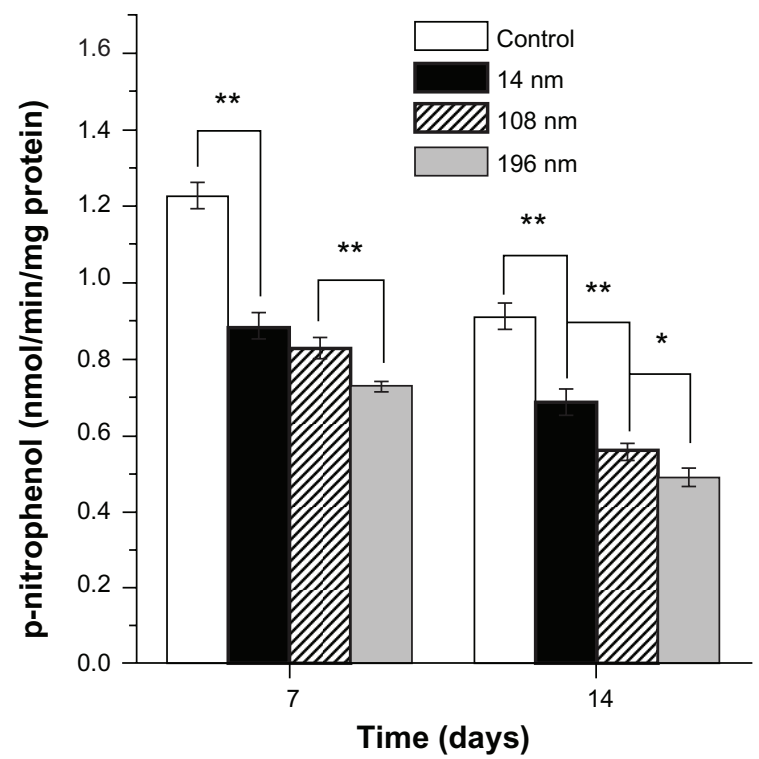

Figure 7 Alkaline phosphatase activity of mesenchymal stem cells cultured with different-sized $\mathrm{TiO}_{2}$ nanoparticles $(0.10 \mathrm{mg} / \mathrm{mL})$ for 7 and 14 days, respectively. Notes: The initial cell seeding density was $2 \times 10^{4} \mathrm{cells} / \mathrm{cm}^{2}$. Error bars represent the mean \pm standard deviation for $\mathrm{n}=6, * \mathrm{p}<0.05$, $* * \mathrm{p}<0.0$ I.

nanoparticles producing oxidative stress as well as reactive oxygen species, leading to cell death. ${ }^{34}$ Furthermore, we confirmed that growth and division of MSC were negatively affected in a size-dependent manner by the $\mathrm{TiO}_{2}$ nanoparticles (Figure 3 and Table 1) potentially via a mechanism causing intracellular acidity, thus inhibiting cell proliferation. ${ }^{46}$

It is well known that uptake of nanoparticles can occur via different pathways in cells, depending on the nanoparticle dimensions. In a previous study, we confirmed that large $\mathrm{TiO}_{2}$ nanoparticles ( $74 \mathrm{~nm}$ and $196 \mathrm{~nm}$ ) were taken up by osteoblasts mainly via clathrin-mediated and caveolae-mediated

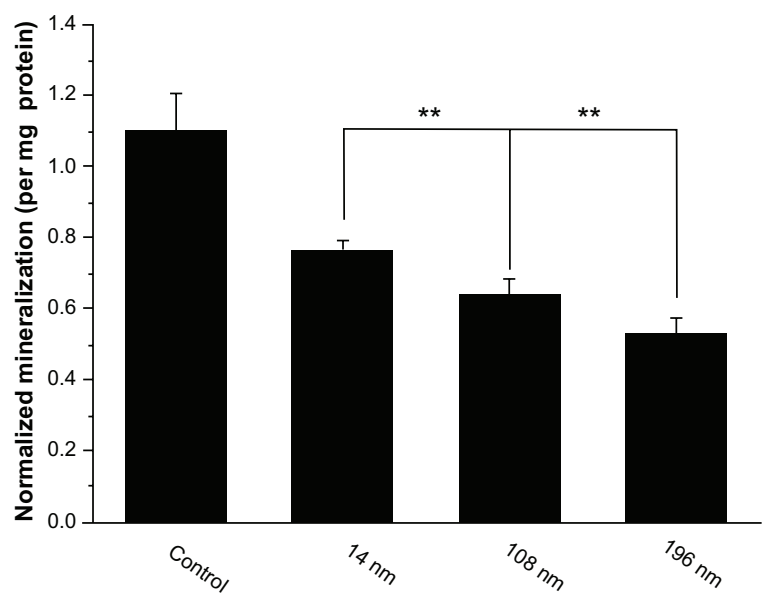

Figure 8 Quantification of cell mineralization. Mesenchymal stem cells were cultured without (control) or with different $\mathrm{TiO}_{2}$ particles $(0.10 \mathrm{mg} / \mathrm{mL})$ for 15 days.

Notes: The initial cell seeding density was $5 \times 10^{4} \mathrm{cells} / \mathrm{cm}^{2}$. Error bars represent the mean \pm standard deviation for $n=6$, $* * P<0.0$ l.

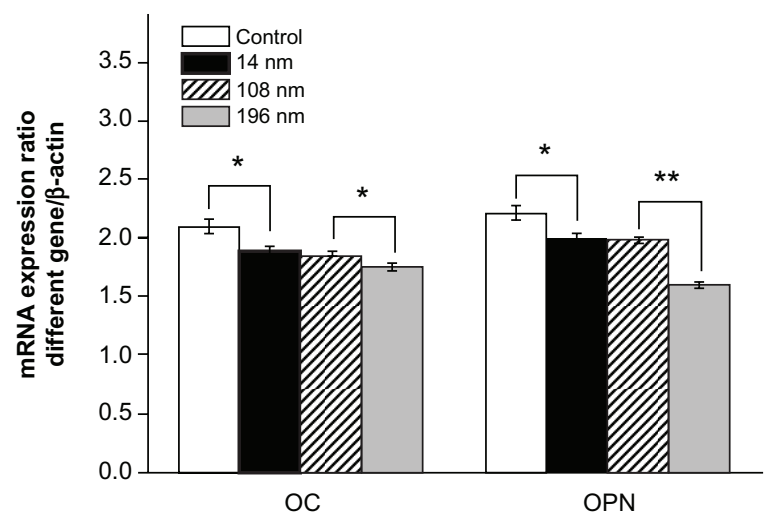

Figure 9 Relative mRNA expression of osteocalcin and osteopontin analyzed by real-time polymerase chain reaction. The mesenchymal stem cells were cultured without or with different $\mathrm{TiO}_{2}$ particles $(0.10 \mathrm{mg} / \mathrm{mL})$ for 14 days.

Notes: The initial cell seeding density was $5 \times 10^{4} \mathrm{cells} / \mathrm{cm}^{2}$. Error bars represent the mean \pm standard deviation for $\mathrm{n}=5$, $* P<0.05$, $* * P<0.01$.

Abbreviations: mRNA, messenger RNA; OC, osteocalcin; OPN, osteopontin.

pathways, whereas small $\mathrm{TiO}_{2}$ nanoparticles $(14 \mathrm{~nm})$ were digested by osteoblasts through a caveolae-mediated pathway. ${ }^{23} \mathrm{We}$ assume that $\mathrm{TiO}_{2}$ nanoparticles were taken up by MSC in a similar manner. In our study, we found that greater amounts of $196 \mathrm{~nm} \mathrm{TiO}_{2}$ nanoparticles accumulated within MSC than did $108 \mathrm{~nm}$ and $14 \mathrm{~nm} \mathrm{TiO}$ nanoparticles (Figure 4A). Previously, Win et al demonstrated that Caco-2 cells took up much fewer $50 \mathrm{~nm}$ PLGA nanoparticles than particles with sizes of 200 and $500 \mathrm{~nm} .{ }^{47}$ Unlike the small $(14 \mathrm{~nm}) \mathrm{TiO}_{2}$ nanoparticles, high accumulation of large $(196 \mathrm{~nm}) \mathrm{TiO}_{2}$ nanoparticles within MSC led directly to more cytotoxicity, in turn affecting biological functions, such as migration, differentiation, and gene expression (Figures 4-9).

The relatively low accumulation of small-sized $(14 \mathrm{~nm})$ $\mathrm{TiO}_{2}$ nanoparticles might be interpreted as meaning that small nanoparticles could escape more easily from endocytic vesicles in cells, thus resulting in limited cytotoxicity to MSC. Pan et al confirmed that $1.2 \mathrm{~nm}$ gold nanoparticles were markedly less cytotoxic than $1.4 \mathrm{~nm}$ gold nanoparticles, despite a three-fold higher concentration. ${ }^{48}$ Another example was internalization of FITC-mesoporous silica nanoparticles that did not affect cell viability, proliferation, or differentiation potential of MSC. ${ }^{49}$ An explanation for this is that FITC-mesoporous silica nanoparticles could escape endosomal vesicles in MSC and retain their architectonic integrity after internalization.

On the other hand, the physicochemical properties (chemistry and surface charge) of a nanoparticle could affect its escape mechanism and potential cytotoxicity. ${ }^{50} \mathrm{~A}$ previous study showed that poly-L-lysine-functionalized PLGA nanoparticles could escape more rapidly and efficiently 
from endosomes than native PLGA nanoparticles and result in 10-fold higher intracellular delivery of an encapsulated model protein. ${ }^{51}$

Although the positive effects of the nanotopography of biomaterials on cell function are well documented, for instance, cell density and cell adhesion are greatly enhanced by surface-nanostructured biomaterials, ${ }^{52,53}$ the present study implies that loss of such a nanoscale structure may have negative effects on cell and tissue function. Thus, ensuring the stability of a nanostructured entity is one of the major concerns when nanostructuring a biomaterial or exploiting a new nanostructured biomaterial, in particular inorganic materials.

\section{Conclusion}

In this study, the cytotoxicity of a series of $\mathrm{TiO}_{2}$ nanoparticles was systematically investigated from the cellular to the molecular level. We confirmed that $\mathrm{TiO}_{2}$ nanoparticles of different sizes have a negative impact on viability, adhesion, migration, proliferation, and differentiation of MSC in a size-dependent and dose-dependent manner. Accumulation of such knowledge might provide new insights into the development of novel nanostructured titanium implants.

\section{Acknowledgments}

This work was financially supported by the China Ministry of Science and Technology (973 Project 2009CB930000), Natural Science Foundation of Chongqing Municipal Government (CSTC, 2011JJJQ10004), Natural Science Foundation of China (11032012, 31170923, 51173216), National Key Technology R\&D Program of the Ministry of Science and Technology (2012BAI18B04), Fok Ying Tung Education Foundation (121035), and the “111” Project (B06023).

\section{Disclosure}

The authors report no conflicts of interest in this work.

\section{References}

1. Long M, Rack HJ. Titanium alloys in total joint replacement - a materials science perspective. Biomaterials. 1998;19(18):1621-1639.

2. Niinomi M. Mechanical biocompatibilities of titanium alloys for biomedical applications. J Mech Behav Biomed Mater. 2008;1(1):30-42.

3. Kubo K, Tsukimura N, Iwasa F, Ueno T, Saruwatari L, Aita H. Cellular behavior on $\mathrm{TiO}_{2}$ nanonodular structures in a micro-to-nanoscale hierarchy model. Biomaterials. 2009;30(29):5319-5329.

4. Zhao G, Raines AL, Wieland M, Schwartz Z, Boyan BD. Requirement for both micron- and submicron scale structure for synergistic responses of osteoblasts to substrate surface energy and topography. Biomaterials. 2007;28(18):2821-2829.

5. Mendonca G, Mendonca DBS, Aragao FJL, Cooper LF. Advancing dental implant surface technology - from micron- to nanotopography. Biomaterials. 2008;29(28):3822-3835.
6. Guida L, Annunziata M, Rocci A, Contaldo M, Rullo R, Oliva A Biological response of human bone marrow mesenchymal stem cells to fluoride-modified titanium surfaces. Clin Oral Implants Res. 2010; 21(11):1234-1241.

7. Annunziata M, Oliva A, Buosciolo A, Giordano M, Guida A, Guida L. Bone marrow mesenchymal stem cell response to nano-structured oxidized and turned titanium surfaces. Clin Oral Implants Res. 2012;23(6): 733-740.

8. Hori N, Iwasa F, Tsukimura N, et al. Effects of UV photofunctionalization on the nanotopography enhanced initial bioactivity of titanium. Acta Biomater. 2011;7(10):3679-3691.

9. McNamara LE, Sjöström T, Burgess KE, et al. Skeletal stem cell physiology on functionally distinct titania nanotopographies. Biomaterials. 2011;32(30):7403-7410.

10. Chen XY, Cai KY, Lai M, Zhao L, Tang LL. Mesenchymal stem cell differentiation on hierarchically micro/nano-structured titanium substrates. Adv Eng Mater. 2012;14(5):B217-B223.

11. Cai KY, Lai M, Yang WH, et al. Surface engineering of titanium with potassium hydroxide and its effects on the growth behaviors of mesenchymal stem cells. Acta Biomater. 2010;6(6):2314-2321.

12. St Pierre CA, Chan M, Iwakura Y, Ayers DC, Kurt-Jones EA, Finberg RW. Periprosthetic osteolysis: characterizing the innate immune response to titanium wear-particles. J Orthop Res. 2010;28(11):1418-1424.

13. Galvin AL, Tipper JL, Ingham E, Fischer J. Nanometer size wear debris generated from crosslinked and non-crosslinked ultra high molecular weight polyethylene in artificial joints. Wear. 2005;259:977-983.

14. Gerhardt $\mathrm{LC}$, Jell GM, Boccaccini AR. Titanium dioxide $\left(\mathrm{TiO}_{2}\right)$ nanoparticles filled poly(D,L lactid acid) (PDLLA) matrix composites for bone tissue engineering. J Mater Sci Mater Med. 2007;18(7):1287-1298.

15. Choi MG, Koh HS, Kluess D, et al. Effects of titanium particle size on osteoblast functions in vitro and in vivo. Proc Natl Acad Sci USA. 2005;102(12):4578-4583.

16. Saldaña L, Vilaboa N. Effects of micrometric titanium particles on osteoblast attachment and cytoskeleton architecture. Acta Biomater. 2010;6(4):1649-1660.

17. Peters K, Unger RE, Kirkpatrick CJ, Gatti AM, Monari E. Effects of nano-scaled particles on endothelial cell function in vitro: studies on viability, proliferation and inflammation. J Mater Sci Mater Med. 2004; 15(4):321-325.

18. Wang JJ, Sanderson BJ, Wang H. Cyto-and genotoxicity of ultrafine $\mathrm{TiO}_{2}$ particles in cultured human lymphoblastoid cells. Mutat Res. 2007;628(2):99-106.

19. Rahman Q, Lohani M, Dopp E, et al. Evidence that ultrafine titanium dioxide induces micronuclei and apoptosis in Syrian hamster embryo fibroblasts. Environ Health Perspect. 2002;110(8):797-800.

20. Ma LL, Liu J, Li N, et al. Oxidative stress in the brain of mice caused by translocated nanoparticulate $\mathrm{TiO}_{2}$ delivered to the abdominal cavity. Biomaterials. 2010;31(1):99-105.

21. Duan YM, Liu J, Ma LL, et al. Toxicological characteristics of nanoparticulate anatase titanium dioxide in mice. Biomaterials. 2010;31(5):894-899.

22. Wang JX, Fan YB, Gao Y, Hu QH, Wang TC. $\mathrm{TiO}_{2}$ nanoparticles translocation and potential toxicological effect in rats after intra-articular injection. Biomaterials. 2009;30(27):4590-4600.

23. Cai KY, Hou YH, Hu Y, et al. Correlation of the cytotoxicity of $\mathrm{TiO}_{2}$ nanoparticles with different particle sizes on a sub-200-nm scale. Small. 2011;7(21):3026-3031.

24. Liu XY, Ren XF, Deng XY, et al. A protein interaction network for the analysis of the neuronal differentiation of neural stem cells in response to titanium dioxide nanoparticles. Biomaterials. 2010;31(33): 3063-3670.

25. Hu Y, Cai KY, Luo Z, et al. Regulation of the differentiation of mesenchymal stem cells in vitro and osteogenesis in vivo by microenvironmental modification of titanium alloy surfaces. Biomaterials. 2012; 33(13):3515-3528.

26. Chen J, Zhou H, Santulli AC, Wong SS. Evaluating cytotoxicity and cellular uptake from the presence of variously processed $\mathrm{TiO}_{2}$ nanostructured morphologies. Chem Res Toxicol. 2010;23(5):871-879. 
27. Zhang YY, Hu L, Yu DH, Gao CY. Influence of silica particle internalization on adhesion and migration of human dermal fibroblasts. Biomaterials. 2010;31(32):8465-8474.

28. Lai M, Cai KY, Zhao L, Chen XY, Hou YH, Yang ZX. Surface functionalization of $\mathrm{TiO}_{2}$ nanotubes with bone morphogenetic protein 2 and its synergistic effect on the differentiation of mesenchymal stem cells. Biomacromolecules. 2011;12(4):1097-1105.

29. Lee HY, Kale GM. Hydrothermal synthesis and characterization of nano-TiO . Int J Appl Ceram Technol. 2008;5(6):657-665.

30. Mahmoudi M, Azadmanesh K, Shokrgozar MA, Journeay WS, Laurent S. Effect of nanoparticles on the cell life cycle. Chem Rev. 2011;111(5): 3407-3432.

31. Liu Y, Li W, Lao F, et al. Intracellular dynamics of cationic and anionic polystyrene nanoparticles without direct interaction with mitotic spindle and chromosomes. Biomaterials. 2011;32(32):8291-8303.

32. Kang SJ, Kim BM, Lee YJ, Chung HW. Titanium dioxide nanoparticles trigger p53-mediated damage response in peripheral blood lymphocytes. Environ Mol Mutagen. 2008;49(5):399-405.

33. Karlsson HL, Cronholm P, Gustafsson J, Möller L. Copper oxide nanoparticles are highly toxic: a comparison between metal oxide nanoparticles and carbon nanotubes. Chem Res Toxicol. 2008;21(9): 1726-1732.

34. Pan Z, Lee W, Slutsky L, Clark RA, Pernodet N, Rafailovich MH. Adverse effects of titanium dioxide nanoparticles on human dermal fibroblasts and how to protect cells. Small. 2009;5(4):511-520.

35. Humphries JD, Wang P, Streuli C, Geiger B, Humphries MJ, Ballestrem C. Vinculin controls focal adhesion formation by direct interactions with talin and actin. J Cell Biol. 2007;179(5):1043-1057.

36. Thurn KT, Arora H, Paunesku T, et al. Endocytosis of titanium dioxide nanoparticles in prostate cancer PC-3M cells. Nanomedicine. 2011;7(2): $123-130$.

37. Hu K, Ji L, Applegate KT, Danuser G, Waterman-Storer CM. Differential transmission of actin motion within focal adhesions. Science. 2007;315(5808):111-115.

38. Hu Y, Cai KY, Luo Z, et al. $\mathrm{TiO}_{2}$ nanotubes as drug nanoreservoirs for the regulation of mobility and differentiation of mesenchymal stem cells. Acta Biomater. 2012;8(1):439-448.

39. Wang ZX, Hou Y, Han W, et al. Effects of hydroxyapatite nanoparticles on apoptosis and invasion of human renal cell carcinoma 786-0 cells. Chem Res Chinese Uni. 2011;27(1):94-98.

40. Gundberg CM, Looker AC, Nieman SD, Calvo MS. Patterns of osteocalcin and bone specific alkaline phosphatase by age, gender, and race or ethnicity. Bone. 2002;31(6):703-708.
41. Dalby MJ, McCloy D, Robertson M, Wilkinson CD, Oreffo RO. Osteoprogenitor response to defined topographies with nanoscale depths. Biomaterials. 2006;27(8):1306-1315.

42. Saldaña L, Sánchez-Salcedo S, Izquierdo-Barba I, et al. Calcium phosphate-based particles influence osteogenic maturation of human mesenchymal stem cells. Acta Biomater. 2009;5(4):1294-1305.

43. Taccola L, Raffa V, Riggio C, et al. Zinc oxide nanoparticles as selective killers of proliferating cells. Int J Nanomedicine. 2011;6:1129-1140.

44. Lock J, Liu H. Nanomaterials enhance osteogenic differentiation of human mesenchymal stem cells similar to a short peptide of BMP-7. Int J Nanomedicine. 2011;6:2769-2777.

45. Jo J, Aoki I, Tabata Y. Design of iron oxide nanoparticles with different sizes and surface charges for simple and efficient labeling of mesenchymal stem cells. J Control Release. 2010;142(3):465-473.

46. Kwon SY, Lin T, Takei H, et al. Alterations in the adhesion behavior of osteoblasts by titanium particle loading: inhibition of cell function and gene expression. Biorheology. 2001;38(2-3):161-183.

47. Win KY, Feng SS. Effects of particle size and surface coating on cellular uptake of polymeric nanoparticles for oral delivery of anticancer drugs. Biomaterials. 2005;26(15):2713-2722.

48. Pan Y, Neuss S, Leifert A, et al. Size-dependent cytotoxicity of gold nanoparticles. Small. 2007;3(11):1941-1949.

49. Huang DM, Hung Y, Ko BS, et al. Highly efficient cellular labeling of mesoporous nanoparticles in human mesenchymal stem cells: implication for stem cell tracking. FASEB J. 2005;19(14):2014-2016.

50. Gan Q, Wang T, Cochrane C, McCarron P. Modulation of surface charge, particle size and morphological properties of chitosan-TPP nanoparticles intended for gene delivery. Colloid Surf B Biointerfaces. 2005;44(2-3):65-73.

51. Vasir JK, Labhasetwar V. Quantification of the force of nanoparticlecell membrane interactions and its influence on intracellular trafficking of nanoparticles. Biomaterials. 2008;29(31):4244-4252.

52. Samaroo HD, Lu J, Webster TJ. Enhanced endothelial cell density on NiTi surfaces with sub-macron to nanometer roughness. Int $J$ Nanomedicine. 2008;3(1):75-82.

53. Tran P, Webster TJ. Enhanced osteoblast adhesion on nanostructured selenium compacts for anti-cancer orthopedic applications. Int $J$ Nanomedicine. 2008;3(3):391-396.
International Journal of Nanomedicine

\section{Publish your work in this journal}

The International Journal of Nanomedicine is an international, peerreviewed journal focusing on the application of nanotechnology in diagnostics, therapeutics, and drug delivery systems throughout the biomedical field. This journal is indexed on PubMed Central, MedLine, CAS, SciSearch $\AA$, Current Contents ${ }^{\circledR} /$ Clinical Medicine,

\section{Dovepress}

Journal Citation Reports/Science Edition, EMBase, Scopus and the Elsevier Bibliographic databases. The manuscript management system is completely online and includes a very quick and fair peer-review system, which is all easy to use. Visit http://www.dovepress.com/ testimonials.php to read real quotes from published authors. 